Published in "Tourism and hospitality research", 2019, vol. 19, no 2, pp. 259-266, which should be cited to refer to this work.

DOI : $\quad 10.1177 / 1467358417743080$

\title{
The impact of service recovery output/process on customer satisfaction and loyalty: The case of the airline industry
}

\begin{abstract}
The purpose of this research is to identify the impact of airline passengers' perception of service recovery output/process on their satisfaction and loyalty. We want to identify the direct and indirect effects of service recovery on airline passenger loyalty by distinguishing the output and the process of the service recovery. A questionnaire was distributed to airline passengers who had a problem during their last airline flight. As we had several latent variables, we used partial least squares (PLS), a variance-based structural equation modeling method. As findings, we observed that in general, clients were not satisfied with the way that the service has been recovered. The most frequent reason for complaining was a problem due to flight delay, followed by a problem with the baggage, overbooking, and flight cancellation. Nevertheless, the findings reveal the positive impact of service recovery's output/process qualities on customer satisfaction and customer loyalty. The output quality of service recovery is the most relevant.
\end{abstract}

Keywords Airline industry, Service recovery, Customer satisfaction, Customer loyalty 


\section{The impact of service recovery on customer satisfaction and loyalty: The case of the airline industry}

\section{INTRODUCTION}

From a customer's perspective, a service failure refers to something that went wrong in dealing with the business or to a real or perceived service related problem (Palmer, 2001; Maxham, 2001). Thus, the expectations of the customer have not been met by the organization (Chan and Wan, 2008) and due to the failure the customer might even perceive a loss (Patterson et al., 2006). Berry (2016) revisiting big ideas in services marketing talks about service recovery through these words: Be great at problem resolution. According to Bejou and Palmer $(2016,1998)$, the airline industry is particularly disposed to service failures due to the service processes employed in service delivery. Although airline passengers may hold certain expectations prior to their impending travel (Coye, 2004), studies concerning the airline industry show a number of reasons that lead to service failures, including flight cancellations, overbooking, strikes, diversions or delays, the attitude of ground/cabin employees and reservation problems (Bamford and Xystouri, 2005). A prior study comparing several US airlines has identified that service failures in regards to service quality occurred due the following seven dimensions: over sales, tour complaints, delays, mishandled baggage problems, advertising complaints, baggage complaints, and flight problem complaints (Gursoy et al., 2005). Edvardsson (1992) found out that delays and cancelled flights accounted for $82 \%$ of dissatisfaction. Specifically, it was the lack of information that was given about the delay that caused the dissatisfaction. Although it is highly unlikely that organizations can eliminate service failures, it is possible to learn how to effectively deal with these failures (through service recovery strategies) with the aim of maintaining and enhancing the satisfaction of the customer (Bamford and Xystouri, 2005; Maxham, 2001; Miller et al., 2000). Although several studies have presented empirical evidence which indicates that relationships between service recovery (interactional, procedural, and distributive justice) and customer satisfaction and loyalty, there is a dearth of empirical research which has assessed the direct and indirect effects of airline passenger perceived service recovery quality on airline passenger loyalty. Indeed, in this research, we want to identify not only the direct impact of service recovery on the passenger satisfaction, but also the direct impact of service recovery on the passenger loyalty. Moreover, it also is the opportunity to observe the evolution in the time of passengers' expectations related to the way that airlines are able to recover a failure. 
Recently, Migacz et al. (2016) found that the most effective recovery strategy for airline management would be to focus on providing compensation beyond customers' expectations.

\section{SERVICE RECOVERY}

Service recovery is the decisions that a company takes in reaction to the service failure (Grönroos, 1990) with the aim of changing the dissatisfaction of the customer to satisfaction and eventually retaining those customers (Bell, 1994; Miller et al., 2000). Previous research identified that service failures offer an opportunity for service recovery, resulting in turning unsatisfied customers into loyal ones. Service recovery is especially relevant in the airline industry, as airlines will, by effectively recovering from service failures, minimize passenger's betrayal and strengthen the relationship with passengers (Christopher et al., 2002). The greatest challenge to effective service recovery is that only $5 \%$ to $10 \%$ of dissatisfied customers choose to complain following a service failure (Tax and Brown, 1998; Dubé and Maute, 1996). Instead, these customers silently switch to competition or make negative word of mouth comments to others (Singh, 1990). The reasons for this reluctance in complaints can be summarized by the following four reasons (Dubé and Maute, 1996; Singh, 1990): i) customers believe that the organization will not respond, ii) customers do not want to confront the individual responsible for the failure, iii) customers are uncertain about their

rights and the firm's obligations, and iv) customers are concerned about the high cost in time and effort of complaining. Thus, in identifying service failures it is important to set performance standards, communicate the importance of service recovery, educate customers to make complaints and implement technological support (e.g. through call centers and the internet) (Dale, 2003). In fact, it is a chance to have customers who complain directly to the company concerned. Service guarantees encourage customers to complain as they affect customer's perceptions of reliability (Hart et al., 1992) but are tenable only where the company is already focused on service quality. Empowering employees is a powerful tool for effective service recovery as the workforce will be able to think for themselves and make decisions of their own for the benefit of the firm's customers (Moore et al., 1998). Boshoff (1997) identified successful recovery strategies after confronting passengers with a negative service situation, in this case a missed flight connection caused by a flight delay. These strategies included a quick reaction and response by an employee having a high position in terms of level of seniority, a fast response accompanied by full refund plus some amount of compensation or a large amount of compensation provided by a high ranking manager. 
Magnini et al. (2007) and Ngai et al. (2007) recommend that a service recovery strategy which was effective could lead to a win-win situation for the customer as well as the company.

The fairness of a service recovery is evaluated by three dimensions according to customers, namely distributive, procedural, and interactional justice. Distributive justice refers to the perceived outcome, whilst procedural justice refers to the perceived processes, and interactional justice refers to interpersonal interactions between customers and employees (Mattila, 2001). Kau and Loh (2006) confirmed that distributive justice is significantly and positively correlated to satisfaction. As far as the procedural justice is concerned, there are six sub-dimensions: flexibility, process control, accessibility, decision control, response speed and acceptance of responsibility (Blodgett and Hill, 1997; Tax and Brown, 1998; Thibaut and Walker, 1975; Del Río-Lanza et al., 2009). Interactional justice concerns the interpersonal interactions during the service recovery process which might include an apology, courtesy and empathy of the staff in dealing with the recovery. It includes the following six subdimensions: courtesy, honesty, offering explanations, empathy, endeavor, and offering apologies (Clemmer, 1988; Tax and Brown, 1998, McColl-Kennedy and Sparks 2003; Del Río-Lanza et al., 2009). Wirtz and Mattila (2004) identified that distributive, procedural and interactional justices all have an effect on satisfaction.

\section{RESEARCH FRAMEWORK AND HYPOTHESES}

Figure 1 shows the research model. The output quality of the service recovery concerns the concrete resolution of the problem. The process quality of the service recovery concerns the overall procedure including the response speed, employees' explanations, empathy, etc. More information will be given in the method chapter.

\section{[Insert Figure 1 here]}

Passengers of airlines are often confronted with service failures such as delay, cancellation, etc. Service failures are considered to be a likely occurrence over a product/service lifetime. However, maintaining customer satisfaction and loyalty mean effectively handling these negative occurrences (Etemad-Sajadi et al., 2016; Fick and Ritchie, 1991; Pritchard and Howard, 1997). Service recovery should thus be a foundation for any 
successful business. According to several authors (i.e. Wirtz and Mattila, 2004; Chang and Chang, 2010; Haverila and Neumann, 2011) service recovery efforts, in particular procedural and interactional justice, have a positive effect on satisfaction. Chang and Chang (2010) found that interactional and procedural justice have a significant effect on recovery satisfaction and the overall satisfaction mediates the relationship between recovery satisfaction and loyalty. Thus, the current research paper will analyze how the service recovery strategy impacts customer satisfaction. More precisely, we want to identify the impact of output quality and process quality of the service recovery on the customer satisfaction. We suggest the following hypotheses:

H1. The higher the perception of service recovery output quality, the higher the customer satisfaction.

H2. The higher the perception of service recovery process quality, the higher the customer satisfaction.

Dubé and Maute (1996) argue that the service recovery strategy of a business has a positive impact on the customer loyalty. Additionally, through the research conducted by Robbins and Miller (2004), it was found that a well-handled service recovery will have a strong impact on customer loyalty. This outcome was also found by Kelley and Swanson (2001) who identified that customer behavioral intentions are more encouraging when customers believe that the business is dependably executing service recovery when failures occur. Thus, we suggest the following hypotheses:

H3. The higher the perception of service recovery output quality, the higher the customer loyalty.

H4. The higher the perception of service recovery process quality, the higher the customer loyalty.

Numerous studies have highlighted the positive influence of customer satisfaction on customer loyalty (Anderson et al., 1994; Ekiz and Arasli, 2007). The higher the satisfaction, the higher the probability of repurchasing and spreading positive word of mouth (Davidow, 2003; Ekiz and Arasli, 2007). As far as airline industry is concerned, several studies have presented empirical evidence which indicates that airline passenger satisfaction has positive direct effects on airline passenger repurchase intentions and willingness to recommend the airline to others (e.g., Nadiri et al., 2008; Park et al., 2006). Thus, we suggest the following hypothesis: 
H5. The higher the customer satisfaction, the higher the customer loyalty.

\section{METHOD}

\subsection{Sampling and Data Collection Procedures}

The questionnaire concentrates on the last airline flight of the passenger who had a problem before/during/after the flight. We did not focus on a specific company, but on the last flight experience of each respondent. In our case, the passengers were travelling with companies such as: Lufthansa, Swiss, British Airways, Easyjet, KLM, Air France, Singapore Airlines, Alitalia, American Airways, Emirates Airlines, Austrian Airlines, Iberia, Turkish Airlines. The quality of service delivered by these companies is very different. However, for this research, the challenge is not to compare the quality delivered by each of these companies, but to identify the impact of service recovery on the general satisfaction and loyalty of the customer. We had 159 respondents in our sample. A paper-and pencil version of our survey was completed by 51 airline passengers at Munich airport. While 108 airline passengers completed an on-line version of our survey which was either sent via email to bachelor of science in international hospitality management students from a private university in Switzerland $(n=97)$ or posted on an airline social media page $(n=11)$; as we highlight below there were no significant differences between these three groups of airline passengers in terms of perceived service recovery, satisfaction, or loyalty. Among the respondents, $52.2 \%$ were male and $47.8 \%$ were female, which can be considered to be a relatively uniform distribution. The age group varied between 19 to 66 years which is considered to be a good representative sample of the age span for the research conducted. During their most recent flight, 110 passengers used air transportation for leisure purposes, 24 passengers flew due to business purposes, and 25 passengers used air transportation for both (leisure and business purposes).

\subsection{Measures}

Airline passenger satisfaction was assessed with the following two items which were adapted the Park et al. (2006) three-item airline passenger satisfaction measure, and others (e.g., Martín-Consuegra et al., 2007; Srivastava \& Rai, 2013): "I am satisfied with my overall experience with this airline" and "My choice to use this airline was a wise one". 
Airline passenger loyalty was assessed with two items from extant "measures of loyalty" (see Jones \& Sasser, 1995, p. 94). More specifically, airline passenger loyalty was assessed with 1) the following item taken from the Nadiri et al. (2008, p. 271) two-item airline passenger repurchase intention measure: "I consider this airline company my first choice for air transportation" and 2) the following item adapted from the Saha and Theingi (2009) twoitem airline passenger repurchase intention measure and extant measures of airline passenger and customer loyalty (see Jones \& Sasser, 1995, pp. 94-95): "I will first consider this airline company even if another company provides the same quality of service." Response options ranged from 1 (strongly disagree) to 7 (strongly agree).

Service recovery items were adapted from Blodgett and Hill (1997) and Wirtz and Mattila (2004). We selected three items regarding service recovery output quality (i.e., "The compensation I received was appropriate", "In resolving the problem, the airline gave me what I needed", etc.) and five items regarding service recovery process quality (i.e., "The airline seemed very concerned about my problem", "The apology received was acceptable", etc.).

The items in Appendix present the operationalization of the model variables. Each question is measured using the seven-point Likert type scale, which is used to agree or disagree with a certain statement.

\subsection{Data analysis method}

Structural equation modeling (SEM) was adopted to test the hypotheses because the model contains latent variables. We chose partial least square (PLS), after having followed the guideline for evaluating and using PLS proposed by Peng and Rai (2012). One major reason comes from the fact that PLS does not require a large sample (Ringle et al., 2012; Hair et al., 2013; Peng and Rai, 2012). SmartPLS 2.0 was used for the analysis. We employed a bootstrapping (400 sub-samples) method to test the significant level of regression path coefficients. Indeed, bootstrapping is the most widely used method for standard error estimation in PLS-SEM.

\section{RESULTS}

\subsection{Descriptive Analysis}

Table 1 shows the descriptive statistics about passengers' perception of the service recovery. In general, we observe that clients were not satisfied with the way that the service 
has been recovered. Indeed, all means are between 3.05 and $4.05 .37 \%$ of passengers answered that they experienced a problem due to a delay. Furthermore, $17 \%$ answered that they experienced a problem due to a baggage complaint, followed by $9 \%$ with a problem due to overbooking, $9 \%$ who experienced a problem due to flight cancellation, and $5 \%$ with other problems (check-in, seat space, assistance after flight, etc.).

\section{[Insert Table 1 here]}

\subsection{Reliability and Validity of Measures}

Table 2 shows that all constructs have a cronbach's alpha higher than (or equal to) 0.7, which confirm that the scale reliabilities have adequate and stable measurement properties. Moreover, all latent variables have a composite reliability higher than 0.8 (See Table 2). Validity is assessed based on three main criteria, namely unidimensionality, convergent, and discriminant validity. An exploratory factor analysis can verify unidimensionality. For each construct, only the first eigenvalue is over one and thus, unidimensionality is confirmed and validated (Dröge, 1996). Convergent and discriminant validity are components of a larger measurement concept known as construct validity (Straub et al. 2004). Convergent validity is shown when each measurement item is strongly correlated with its construct. It is usually satisfied by retaining variables whose loadings are greater than 0.5 , indicating that they share sufficient variance with their related construct. In order to check the convergent validity, each latent variable's Average Variance Extracted (AVE) is evaluated. All of the AVE values are greater than the acceptable threshold of 0.5 , so convergent validity is confirmed (See Table 2). Discriminant validity is confirmed when each measurement item is weakly correlated with all other constructs except with the one to which it is theoretically associated (Gefen and Straub, 2005). Table 2 shows the intercorrelation of the research constructs. The diagonal of this matrix represents the square root of the Average Variance Extracted. For adequate discriminant validity, the diagonal elements should be significantly larger than the correlation of the specific construct with any of the other constructs and should be at least 0.5 (Fornell and Larcker, 1981). In our case, discriminant validity is confirmed and sufficient to support the model. Finally, in order to assess the collinearity, we did the variance inflation factor (VIF) test. A VIF higher than five is problematic (Hair et al., 2011). In our case, all VIF are lower than five. 


\section{[Insert Table 2 here]}

\subsection{Results and Discussion}

Figure 2 shows the results of the PLS analysis. We observe the values of different path coefficients and see that the independent latent variables explain $32 \%$ of variance of the dependent variable called customer satisfaction.

Starting by looking at the impact of service recovery on customer satisfaction, one can claim that the output quality of the recovery is the most significant $(\gamma=0.404$, $t$-value $=5.490)$. The impact of the process quality of the service recovery is also significant $(\gamma=0.206$, t-value $=$ 2.606), but it is less important than the output quality. Hence $\mathrm{H} 1$ and $\mathrm{H} 2$ are supported. As far as the $\mathrm{H} 3$ and $\mathrm{H} 4$ are concerned, the output and process quality of the service recovery significantly impact customer loyalty (respectively $\gamma=0.175$, t-value $=2.367$ and $\gamma=0.152$, $t$ value $=2.188$ ). These results confirm the importance of a good strategy of service recovery in order to satisfy and render loyal the passengers. Airlines frequently suffer from some form of service failure such as baggage complaint, overbooking or delayed flights. In our case flight delays were the most experienced problem encountered by passengers. It confirms the findings of Edvardsson (1992) putting the accent on flight delays. Unfortunately this service failure is often not in the control of the carrier and thus hard to solve. However, airlines can make the perceived waiting time shorter by for instance offering snacks and beverages. Most passengers do not believe that the airline gave them what they needed when trying to resolve the problem and neither did the airline seem very concerned about the problem in the eyes of the passenger. Finally, we confirmed the positive impact of passenger satisfaction on his/her loyalty $(\gamma=0.470, t$-value $=10.254)$. Even if this is not a surprise, it is interesting to see that this link is confirmed in the airline industry.

\section{[Insert Figure 2 here]}

\subsection{Managerial Implications}

A good service recovery strategy implies constant costs. Constant staff training is vital in order to implement an effective service recovery strategy. Service managers need to understand the significance of the "recovery process" and that its objective is not only to remove dissatisfaction but also to improve satisfaction. Airlines, as well as other industries, can identify points of failure by making a monthly or quarterly comparison of results and examining the main complaints during these periods. It is essential for companies to use this 
information wisely in order to improve the customers' experience in an effective manner. Efficient systems need to be in place to identify the severity of each failure (Sengupta et al., 2015) in order to recover the situation and thus enhance satisfaction and ultimately loyalty. Airlines can put in place an effective program which is designed to engage staff at all levels. For example, US Airways created a "Learning Map" module which had the aim of providing reliable operations and service recovery. Singapore Airlines also has a very detailed service recovery strategy which had a good reputation throughout the past years. A customer journey mapping can also be implemented by carriers to truly understand the feelings of passengers and the corresponding service solution. Through a customer journey mapping connected to the internal customer relationship management (CRM) system, companies can recognize specific failures during each touch point and identify feelings of each persona (i.e. business traveler, leisure traveler, traveler with kids, etc.) and based on that, they can bring concrete adapted solutions.

\subsection{Limitations}

This study is subject to some limitations. First, airlines are not in charge of all touch points. Thus, the answers also depend on the organization of each airport. Second, we asked passengers to give their point of view about a failure happened during their most recent flight experience. Third, passengers were travelling with companies delivering very different levels of service. Hence, passenger expectations related to service recovery vary based on the selected airline. However, the challenge was not to compare the quality delivered by each airline. The goal was to detect the impact of service recovery on passenger satisfaction and loyalty. Fourth, as we selected several different ways for distributing our survey, there is a risk of bias. Fifth, the questionnaire was conducted in English. Therefore, as the sample is unable to represent the entire population of airline customers, some caution should be exercised in interpreting the results of the study. In the future, it can be interesting to translate the questionnaire in different languages and to observe also the moderating role of the culture on the different relationships. 


\section{References}

Anderson, E., Fornell, C., and Lehmann, D. 1994. Customer satisfaction, market share and profitability: Finding from Sweden. Journal of Marketing 58(32), 53-66.

Bamford, D. and Xystouri, T. 2005. A case study of service failure and recovery within an international airline. Managing Service Quality 15(2), 306-322.

Bell, C. R. 1994. Turning disappointment into customer delight. Editor \& Publisher 127 (32), 38-48.

Bejou, D. and Palmer, A. 1998. Service failure and loyalty: an exploratory empirical study of airline customers. Journal of Services Marketing 12(1), 7-22.

Berry, L. 2016. Revisiting "big ideas in services marketing" 30 years later, Journal of Services Marketing 30(1), 3-6.

Blodgett, J. and Hill, D. 1997. The effects of distributive, procedural, and interactional justice on post-complaint behavior. Journal of Retailing 73(2), 185-210.

Boshoff, C. 1997. An experimental study of service recovery options. International Journal of Service Industry Management 8(2), 110-130.

Chan, H. and Wan, L. 2008. Consumer responses to service failures: a resource preference model of cultural influences. Journal of International Marketing 16(1), 72-97.

Chang, Y. W. and Chang, Y. H. 2010. Does service recovery affect satisfaction and customer loyalty? An empirical study of airline services. Journal of Air Transport Management 16(6), 340-342.

Chin, W. W. 2010. How to write up and report PLS analyses. In Handbook of partial least squares (pp. 655-690). Springer Berlin Heidelberg.

Christopher, M., Ballantyne, D., and Payne, A. 2002. Relationship marketing: creating stakeholder value. Oxford: Butterworth-Heinemann.

Clemmer, E.C. 1988. The role of fairness in customer satisfaction with services. University of Maryland, College Park, MD.: Doctoral dissertation, Psychology Department.

Coye, R. 2004. Managing customer expectations in the service encounter. International Journal of Service Industry Management 5(1), 54-71.

Dale, B. G. 2003. Managing quality (4th ed.). Oxford: Blackwell Publishing.

Del Río-Lanza, A.B., Vázquez-Casielles, R., and Díaz-Martín, A.M. (2009). Satisfaction with service recovery: Perceived justice and emotional responses. Journal of Business Research 62(8), 775-781.

Dröge, C. (1996), "How valid are measurements?”, Research Issues, Eli Broad Graduate School of Management, Michigan State University. 
Dubé, L. and Maute, M. 1996. The antecedents of brand switching, brand loyalty and verbal responses to service failures, in Swartz, T., Bowen, D. and Brown, S. (Eds), Advances in Services Marketing and Management 5, JAI Press, Greenwich, CT , 127-151.

Edvardsson, B. 1992. Service breakdowns: a study of critical incidents in an airline. International Journal of Service Industry Management 3(4), 17-29.

Ekiz, H. and Arasli, H. 2007. Measuring the impacts of organizational responses: case of Northern Cyprus hotels. Managing Global Transitions: International Research Journal 5(3), 271-287.

Etemad-Sajadi, R., Way, S. A., \& Bohrer, L. 2016. Airline Passenger Loyalty The Distinct Effects of Airline Passenger Perceived Pre-Flight and In-Flight Service Quality. Cornell Hospitality Quarterly 57(2), 219-225.

Fick, G. R., and Ritchie, J. B. 1991. Measuring service quality in the travel and tourism industry. Journal of Travel Research 30(2), 2-9.

Fornell, C.R. and Larcker, D. 1981. Evaluating structural equation models with unobservable variables and measurement error. Journal of Marketing Research 18, 39-50.

Gefen, D. and Straub, D. 2005. A practical guide to factorial validity using Pls-graph: tutorial and annotated example. Communications of the Association for Information Systems 16(5), 91-109.

Grönroos, C. 1990. Relationship marketing approach to the marketing function in service contexts: the marketing and organizational behavior influence. Journal of Business Research 20(1), 3-12.

Gursoy, D., Chen, M., and Kim, H. 2005. The US airlines relative positioning based on attributes of service quality. Tourism Management 26, 57-67.

Hair, J. F., Ringle, C. M., \& Sarstedt, M. 2013. Editorial-partial least squares structural equation modeling: Rigorous applications, better results and higher acceptance. Long Range Planning, 46(1-2), 1-12.

Hair, J. F., Ringle, C. M., \& Sarstedt, M. 2011. PLS-SEM: Indeed a silver bullet. Journal of Marketing Theory and Practice 19(2), 139-151.

Hart, C., Schlesinger, L., and Maher, D. 1992. Guarantees come to professional service firms. Sloan Management Review 33(3), 19-29.

Haverila, M., and Naumann, E. 2011. Customer complaint behavior and satisfaction in a B2b context: A longitudinal analysis. Journal of Services Research 10(2), 45-62.

Jones, T.O. and Sasser, W.E. 1995. Why satisfied customers defect. Harvard Business Review, 73(6), 88-102. 
Kau, A.k. and Loh, W.Y. 2006. The effects of service recovery on consumer satisfaction: a comparison between complainants and non-complainants. Journal of Services Marketing 20(2), 101-111.

Magnini, V., Ford, J., Markowski, E., and Honeycutt, E. 2007. The service recovery paradox: justifiable theory or smoldering myth?. Journal of Services Marketing 21(3), 213-225.

Martín-Consuegra, D., Molina, A., and Esteban, Á. 2007. An integrated model of price, satisfaction and loyalty: An empirical analysis in the service sector. Journal of Product \& Brand Management 16(7), 459-468.

Mattila, A.S. 2001. The effectiveness of service recovery in a multi-industry setting. Journal of Services Marketing 15(7), 583-596.

Maxham, J.G. 2001. Service recovery's influence on consumer satisfaction, positive word-ofmouth, and purchase intentions. Journal of Business Research 54(1), 11-24.

McColl-Kennedy, J. and Sparks, B. 2003. Application of fairness theory to service failures and service recovery. Journal of Service Research 5, 251-267.

Migacz, S.J., Zou, S., and Petrick, J.F. 2016. The "Terminal" Effects of Service Failure on Airlines: Examining Service Recovery with Justice Theory, Journal of Travel Research, 1-16.

Miller, J., Craighead, C., and Karwan, K. 2000. Service recovery: a framework and empirical investigation. Journal of Operations Management 18, 387-400.

Moore, G., Hopkins, W., and Hopkins, S. 1998. Quality and empowerment: dual paths to customer satisfaction?. Managing Service Quality 8(2), 133-141.

Nadiri, H., Hussain, K., Ekiz, E. H., and Erdogan, S. 2008. An investigation on the factors influencing passengers' loyalty in the North Cyprus national airline. The TQM Journal, 20(3), 265-280.

Ngai, E., Heung, V., Wong, Y., and Chan, F. 2007. Consumer complaint behaviour of Asians and non-Asians about hotel services: an empirical analysis. European Journal of Marketing 41(11/12), 1375-1391.

Palmer, A. 2001. Principles of services marketing (3 ed.). Singapore: McGraw-Hill.

Palmer, A., Bejou, D. 2016. Retrospective: service failure and loyalty: an exploratory empirical study of airline customers, Journal of Services Marketing 30(5), 480-484.

Park, J.-W., Robertson, R., and Wu, C.-L. 2006. Modelling the impact of airline service quality and marketing variables on passengers' future behavioural intentions. Transportation Planning and Technology 29(5), 359-381.

Patterson, P., Cowley, E., and Prasongsukarn, K. 2006. Service failure recovery: the moderating impact of individual-level cultural value orientation on perceptions of justice. International Journal of Research in Marketing 23(3), 263-277. 
Peng, D. X., \& Lai, F. 2012. Using partial least squares in operations management research: A practical guideline and summary of past research. Journal of Operations Management, 30(6), 467-480.

Pritchard, M. P., \& Howard, D. R. 1997. The loyal traveler: Examining a typology of service patronage. Journal of Travel Research 35(4), 2-10.

Robbins, T. and Miller, J. 2004. Considering customer loyalty in developing service recovery strategies. Journal of Business Strategies 21(2), 95-109.

Ringle, C. M., Sarstedt, M., \& Straub, D. 2012. A critical look at the use of PLS-SEM in MIS Quarterly. MIS Quarterly (MISQ) 36(1).

Saha, G.C. and Theingi. 2009. Service quality, satisfaction, and behavioral intentions: A study of low-cost airline carriers in Thailand. Managing Service Quality 19(3), 350-372.

Sengupta, A. S., Balaji, M. S., and Krishnan, B. C. 2015. How customers cope with service failure? A study of brand reputation and customer satisfaction. Journal of Business Research 68(3), 665-674.

Singh, J. 1990. A typology of consumer dissatisfaction response styles. Journal of Retailing 66(1), 57-99.

Srivastava, M. and Rai, A.K. 2013. Investigating the mediating effect of customer satisfaction in the service quality-customer loyalty relationship. Journal of Consumer Satisfaction, Dissatisfaction \& Complaining Behavior 26, 97-109.

Straub, D., Boudreau, M.C. and Gefen, D. 2004. Validation guidelines for IS positivist research. Communications of the Association for Information Systems 14, 380-426.

Tax, S., and Brown, S. 1998. Customer evaluation of service complaint experiences: implications for relationship marketing. Journal of Marketing 62, 60-76.

Thibaut, J.W. and Walker, L. 1975. Procedural justice: A psychological analysis (pp. 11411160). Hillsdale, NJ; New York, NY: L. Erlbaum Associates.

Wirtz, J., and Mattila, A. 2004. Consumer responses to compensation speed of recovery and apology after a service failure. International Journal of Service Industry Management 15(2), 150-166. 
Appendix: Questionnaire items

\section{Service recovery output quality}

SROQ1: The airline provided a satisfactory resolution to the problem in this particular situation.

SROQ2: The compensation I received was appropriate.

SROQ3: In resolving the problem, the airline gave me what I needed.

\section{Service recovery process quality}

SRPQ1: The airline seemed very concerned about my problem.

SRPQ2: The airline handled my complaint in a thoughtful manner.

SRPQ3: The speed of recovery was acceptable.

SRPQ4: The apology received was acceptable.

SRPQ5: An explanation of the service failure was offered.

\section{Satisfaction}

SAT1: I am satisfied with my overall experience with the airline.

SAT2: My choice to use this airline was a wise one.

\section{Loyalty}

LOY1: I will consider this airline company even if another company provides the same quality.

LOY2: I consider the airline company my first choice for air transportation.

LOY3: I would recommend the airline to others.

Notes:

- All items in each construct were evaluated on a 1 to 7 scale with 1 being "strongly disagree" and 7 being "strongly agree" 
Figure 1

Research model

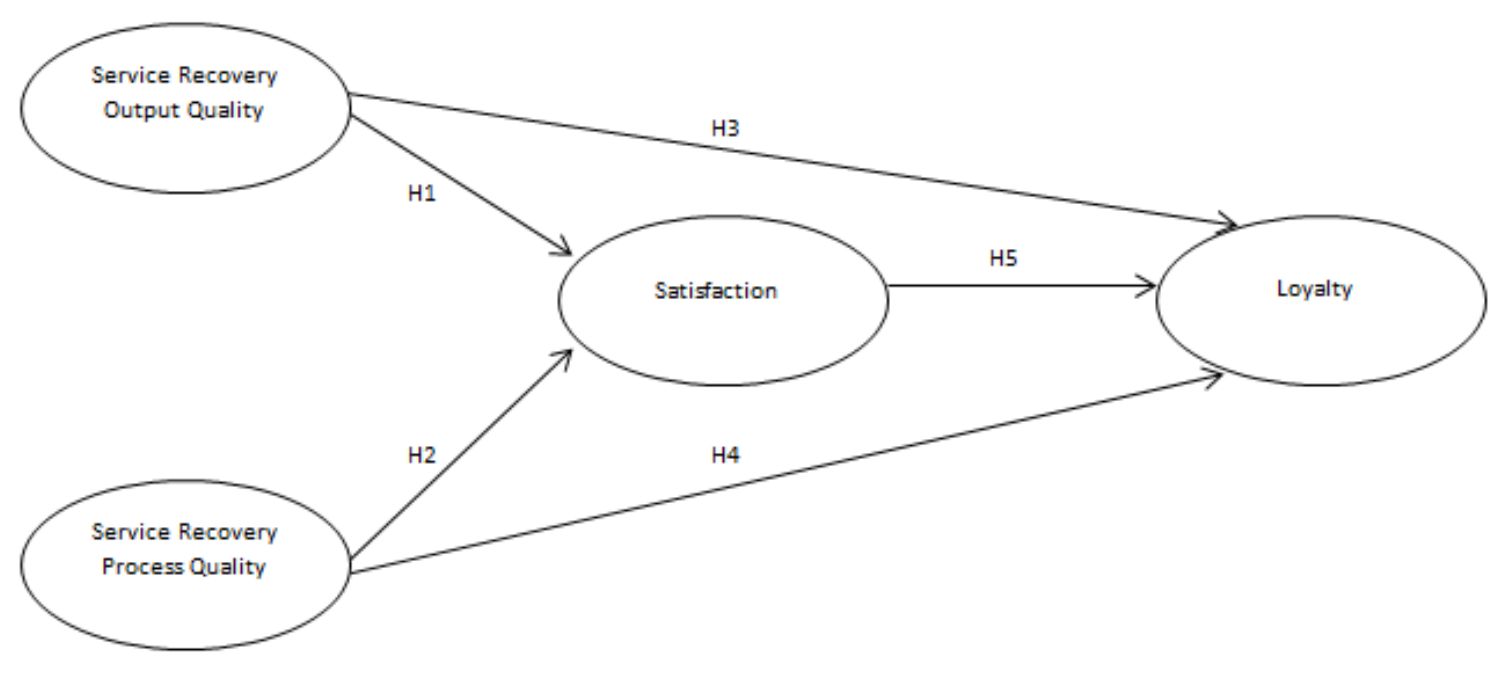


Figure 2

Results of the PLS analysis

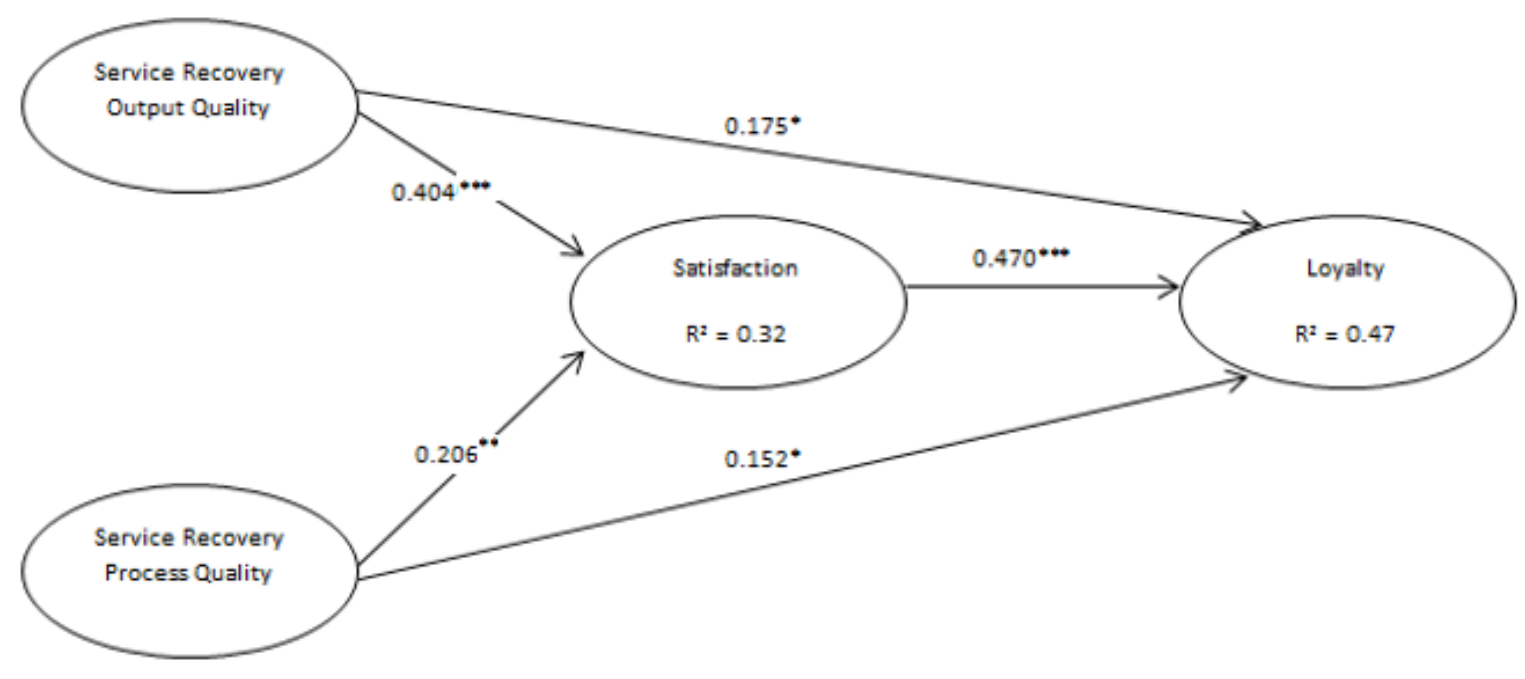

Notes:

* Significant at 0.05 level.

** Significant at 0.01 level.

$* * * \quad$ Significant at 0.001 level. 
Table 1

Perception of the service recovery (mean and standard deviation)

\begin{tabular}{|l|r|r|r|r|}
\hline Indicators & Mean & \multicolumn{1}{|c|}{$\begin{array}{l}\text { Standard } \\
\text { deviation }\end{array}$} & Min & Max \\
\hline $\begin{array}{l}\text { The airline provided a satisfactory resolution to } \\
\text { the problem in this particular situation }\end{array}$ & $\mathbf{3 . 9 1}$ & 2.10 & 1 & 7 \\
\hline The compensation I received was appropriate & $\mathbf{3 . 4 3}$ & 2.00 & 1 & 7 \\
\hline $\begin{array}{l}\text { In resolving the problem, the airline gave me } \\
\text { what I needed }\end{array}$ & $\mathbf{3 . 0 5}$ & 1.56 & 1 & 7 \\
\hline $\begin{array}{l}\text { The airline seemed very concerned about my } \\
\text { problem }\end{array}$ & $\mathbf{3 . 0 6}$ & 1.72 & 1 & 7 \\
\hline $\begin{array}{l}\text { The airline handled my complaint in a } \\
\text { thoughtful manner }\end{array}$ & $\mathbf{3 . 8 4}$ & 1.73 & 1 & 7 \\
\hline The speed of recovery was acceptable & $\mathbf{4 . 0 5}$ & 1.83 & 1 & 7 \\
\hline The apology received was acceptable & $\mathbf{3 . 9 5}$ & 2.03 & 1 & 7 \\
\hline $\begin{array}{l}\text { An explanation of the service failure was } \\
\text { offered }\end{array}$ & $\mathbf{3 . 9 1}$ & 2.07 & 1 & 7 \\
\hline
\end{tabular}


Table 2

Reliability and discriminant validity

\begin{tabular}{|l|r|c|c|c|r|r|r|}
\hline Constructs & $\alpha^{\mathbf{a}}$ & $\begin{array}{c}\text { Composite } \\
\text { reliability }\end{array}$ & AVE & $\mathbf{1}$ & $\mathbf{2}$ & $\mathbf{3}$ & $\mathbf{4}$ \\
\hline 1. Service recovery output quality & .85 & .91 & .77 & $.87^{\mathbf{b}}$ & & & \\
\hline 2. Service recovery process quality & .83 & .88 & .66 & $.74^{* *}$ & .81 & & \\
\hline 3. Satisfaction & .86 & .93 & .88 & $.55^{* *}$ & $.50^{* *}$ & .93 & \\
\hline 4. Loyalty & .80 & .88 & .71 & $.54^{* *}$ & $.51^{* *}$ & $.64^{* *}$ & .84 \\
\hline
\end{tabular}

Notes:

* Correlation is significant at the 0.05 level.

** Correlation is significant at the 0.01 level.

a Cronbach's Alpha

b Diagonal: (Average Variance Extracted $)^{1 / 2}=\left(\Sigma \lambda_{\mathrm{i}}{ }^{2} / \mathrm{n}\right)^{1 / 2}$ 